This article was downloaded by: [Monash University Library]

On: 04 February 2015, At: 05:53

Publisher: Routledge

Informa Ltd Registered in England and Wales Registered Number: 1072954

Registered office: Mortimer House, 37-41 Mortimer Street, London W1T

3J H, UK

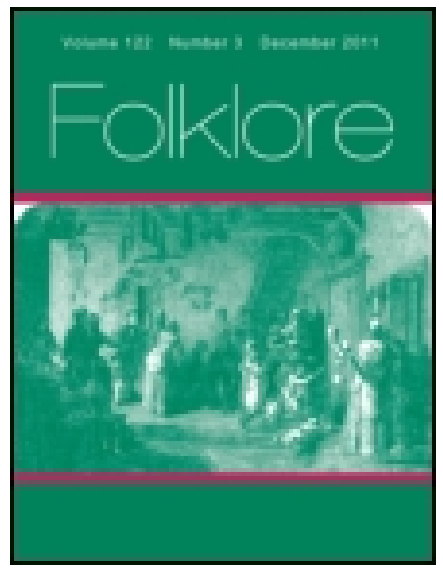

\title{
Folklore
}

Publication details, including instructions for authors and subscription information:

http:// www. tandfonline.com/loi/ rfol20

\section{Superstitions and Survivals Amongst Shepherds}

E. Lovett

Published online: 14 Feb 2012.

To cite this article: E. Lovett (1909) Superstitions and Survivals Amongst Shepherds, Folklore, 20:1, 63-70, DOI: 10.1080/ 0015587X.1909.9719860

To link to this article: http:// dx.doi.org/ 10.1080/ 0015587X.1909.9719860

\section{PLEASE SCROLL DOWN FOR ARTICLE}

Taylor \& Francis makes every effort to ensure the accuracy of all the information (the "Content") contained in the publications on our platform. However, Taylor \& Francis, our agents, and our licensors make no representations or warranties whatsoever as to the accuracy, completeness, or suitability for any purpose of the Content. Any opinions and views expressed in this publication are the opinions and views of the authors, and are not the views of or endorsed by Taylor \& Francis. The accuracy of the Content should not be relied upon and should be independently verified with primary sources of information. Taylor and Francis shall not be liable for any losses, actions, claims, proceedings, demands, costs, expenses, damages, and other liabilities whatsoever or howsoever caused arising directly or indirectly in connection with, in relation to or arising out of the use of the Content.

This article may be used for research, teaching, and private study purposes. Any substantial or systematic reproduction, redistribution, reselling, loan, sub-licensing, systematic supply, or distribution in any form to anyone is 
expressly forbidden. Terms $\&$ Conditions of access and use can be found at http://www.tandfonline.com/page/terms-and-conditions 


\section{COLLECTANEA.}

SUPERSTITIONS AND SURVIVALS AMONGST SHEPHERDS.

(With Plates I. AND II.)

(Read at Meeting, November I9th, 1908.)

During a visit of a few days to the South Downs in the latter part of this year (1908), I searched for any folk beliefs and primitive appliances still lingering amongst the shepherds. Most of the shepherds are natives of the district, and nearly all descend from a long line of shepherds, and so may be expected still to hold to ancient customs and ideas. The notes I gathered are undoubtedly very incomplete, partly by reason of the short time available for enquiries during my visit, but chiefly from the difficulty of getting those who still believe in charms and magic to "own up," and to talk about the practices in which they still indulge. I found that here, as elsewhere, a great change is taking place, and that it is probable that, not many years hence, there will no longer be men to be found who use the tallies and sundials described below.

Many of the beliefs and customs observed,-such as the unlucky character of Friday and of the number 13 , and the carrying of a potato as a cure for rheumatism,-are too widely spread and familiar to be worth recording, but the following items appear to be of a less usual character.

To cure toothache, a "thistle nut" is carried in the pocket. This is not the bud of the thistle, but apparently a gall which is sometimes found at the side of the stem. 
PLATE I.

FIG. I

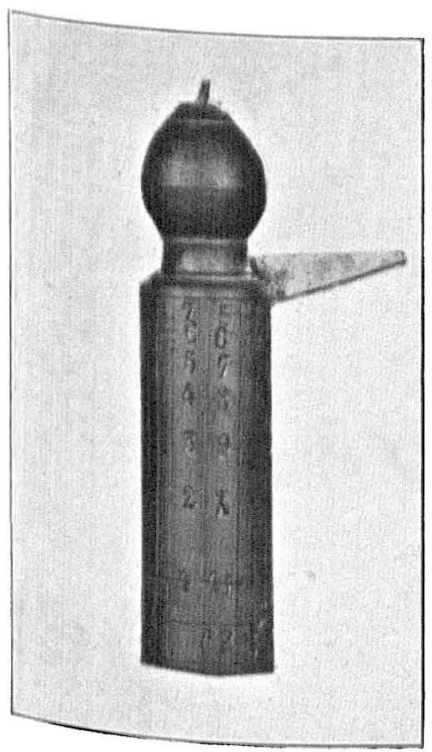

FIG. 3.

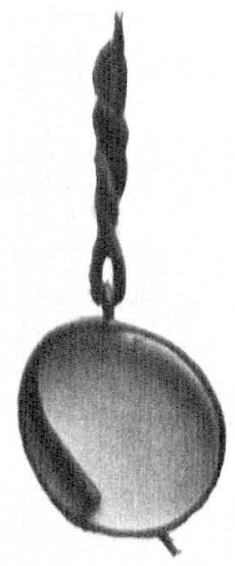

FIG. 2 .

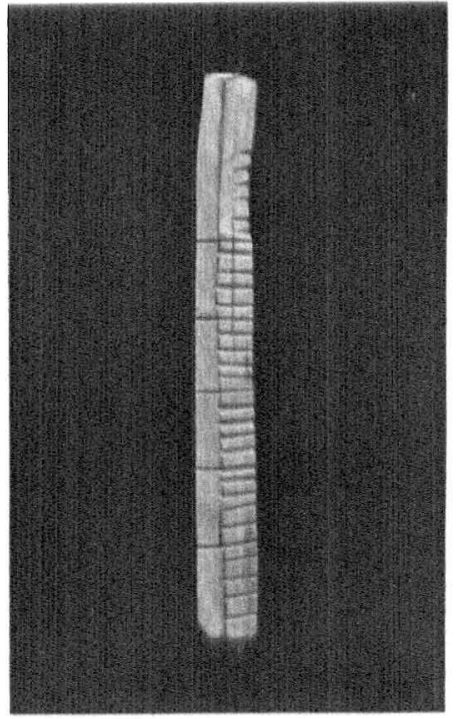

FIG. 4.

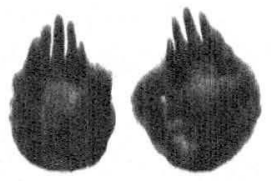

FIG. 5.
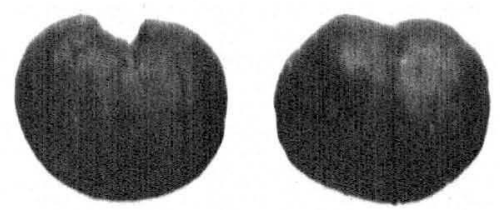

l.comardsen or (i) 
Cramp seems to be prevalent, as amulets for its cure are to be heard of everywhere. The digging feet of moles, Fig. 4 (Plate I.), are looked on as the most efficacious charms, perhaps because the cramped appearance of the curved foot has led to the application to it of the doctrine that "like cures like." The moles' feet are either carried loose in the pocket, or put into a little silk bag and bung round the neck next the skin. Fig. 5 (Plate I.) shows another favourite cramp charm, in the form of "cramp nuts," which are small woody concretions found upon the trunks of both beech and ash trees. The particular tree preferred as a source of the "cramp nuts" varies according to the locality, but I was not able to ascertain any reason for the preference. The nuts shown were obtained from an ash tree, The "cramp nuts" are either carried loose in the pocket or tied up in little pieces of rag and fastened to the bedstead of the sufferer from cramp. I may note here that near Whitstable the name "cramp stone" is given to the fossil shark's teeth, with a limy concretion near the base, which are there found in the beds of London Clay and looked on as amulets against cramp.

I was informed by Mr. Alfred J. Collyer, of Peppering, that some years ago a villager near Burpham had some pigs which sickened owing to their having been "overlooked." Upon the death of one of these pigs, the owner took out its heart, stuck nails and pins into it, and roasted it before the fire, having first shut up securely all the doors and windows. This brought about such misfortunes to the person with the evil eye that the local charmer intervened to remove the spell, but afterwards the pigs flourished.

The recording of numbers by means of notches on tally sticks is still practised by a few shepherds of the old school, and I obtained specimens of flock tallies and lamb tallies. These are cut either on squared lengths of wood about half an inch wide and eight or nine inches long, or on natural round sticks of about the same size and with the bark left on.

In the lamb tallies used for recording the number of lambs born in the lambing season, an ordinary notch denotes doubles or twins (the normal birth), a short notch or dot a single birth, 
and, perhaps, an extra long notch trebles. (In Worcestershire the doubles are similarly marked by ordinary notches, but the singles and trebles by black and red coloured notches). By this simple method a shepherd can very quickly record and "tot up" the number of his lambs.

The flock tallies are used when the lambs are old enough to leave the ewes, and the time has come for dividing up the flock. In dividing, the animals are separated by twenties, or by the "score" (i.e. by the scratch or notch). After five "scores" have been made, the fifth notch is continued, either over the edge of a squared tally, or further round a natural bark-stick tally than the other notches, so that the hundreds on the tally can be read off simply and easily. Any odd animals are marked by smaller notches at the end of the row, so that, for a new flock of, say, 6I3 sheep, the completed tally would show six sets of five notches each, followed by thirteen smaller notches, thus,-

$$
1111|1111| 1111|1111| 1111|1111| 111111111111
$$

Fig. 2 (Plate I.) shows an actual flock tally recording 506 sheep.

One of the old shepherds made a very remarkable tally for me, saying that his grandfather used one like it. It consists of a piece of natural wood, with the bark on, about one inch in diameter and six inches long. This is hollowed out, and the ends stopped with two bits of cork. In this wooden bottle are placed small pebbles, each one representing a score of sheep, and the odd sheep are notched upon the bark in the same way as on the ordinary tally. In this tally a flock of 613 sheep would be recorded by thirty small pebbles and thirteen notches.

In the same locality,-Burpham, near Arundel,-tallies are still sometimes used for other purposes than those described above. For example, when a man buys lambs for feeding up, he will have a record of the original number in stock, and will keep a tally record of the deaths. Farm carters also use tallies for recording the number of cartloads moved of manure or of stones, and most of the older men well remember the "score" of cricket matches being kept by notching sticks. 
I an strongly of opinion that the Biblical narrative of the bargain between the shepherds Jacob and Laban (Genesis, Chapter XXX.), which is at present admittedly in an obscure and confused condition, might be rendered more intelligible by regarding it from the standpoint of the use of tallies by Jacob (verses $37-8$ ). So far as I am aware, after an extended search, no suggestion has hitherto been made of such an explanation, which I consider worthy of further investigation and of separate treatment.

An even more interesting survival than the sheep tally occurs amongst the shepherds of the South Downs. A turf sundial is still to be found in use in a few places, from which the cheap watch has not yet driven it. A shepherd, after feeding his flock on roots where they have been "folded" for the night, will take them on to the grassy downs, returning with them when it is time for the night folding. In order to do this he must know at what hour to begin his return journey, for he may have a long distance to go. If without a watch, and with no clocks within hearing, he resorts to one of the turf dials shown in Plate II. If the sun fails him, and his dial consequently does not work, he has to work by dead reckoning. In some cases the old shepherds can make very good estimates of the time without either watch, sundial, or visible sun.

The form of sundial photographed in Fig. 6 is made as follows:-Having selected a fairly smooth bit of turf, the shepherd marks a rough circle about eighteen inches in diameter with a pointed stick, leaving the stick perpendicularly in the ground in the centre. Due south of this he fixes another stick, about twelve inches long, on the periphery of the circle. The south direction is either ascertained at mid-day by means of another man's watch, or, more frequently, by landmark bearings known to the shepherd. Having done this, he fixes another stick due west, which is, of course, merely a matter of measurement. He then fixes in the intervening quadrant of the circle five sticks for the hours one to five inclusive, so completing a sundial with Beven gnomons on its circumference. At three o'clock in an October afternoon, which is about the time shown in the photograph, it may be about time to return to the fold, and the 
shadow of the third stick from the mid-day gnomon will then fall on the central stick, and the shepherd will know that it is time to start.

Another form of turf dial is photographed in Fig. 7 and is much more similar to the ordinary garden sundial. The central stick is the gnomon, and a stick notched for the hours is laid across the ends of two other sticks pointing due north and due east. I have also seen hour sticks placed at regular intervals from north to east for the shadow of the central gnomon to fall upon them.

The only reference I have been able to find to the former use of these turf dials by shepherds occurs in Shakespeare's King Henry VI., Third Part, Act ii. Sc. v., but perhaps refers to a more elaborate turf copy of the ordinary dial than those described :

\footnotetext{
"O God! methinks it were a happy life To be no better than a homely swain; To sit upan a hill, as I do now, To carve out dials quaintly, point by point, Thereby to see the minutes how they run: How many make the hour full complete, How many hours bring about the day, How many days will finish up the year, I ow many years a mortal man may live. When this is known, then to divide the times: So many hours must I tend my flock, So many hours must I take my rest, So many hours must I sport myself, So many days my ewes have been with young, So many weeks ere the poor fools will yean, So many years ere I shall shear the fleece: So minules, hours, days, munths, and years l'ass'd over to the end they were created, Would bring white hairs unto a quiet grave."
}

The late Mrs. Gatty writes (The Book of Sun-dials, edit. I900, p. 24), that "to 'carve out dials' was the way in which the shepherd boy beguiled his time," and apparently supposes the above passage to refer to the carving out of portable sundials. Such portable sundials were well known in the fourteenth century, and in the following century they grew to be regarded as travel- 
PLATE II.

FIG. 6

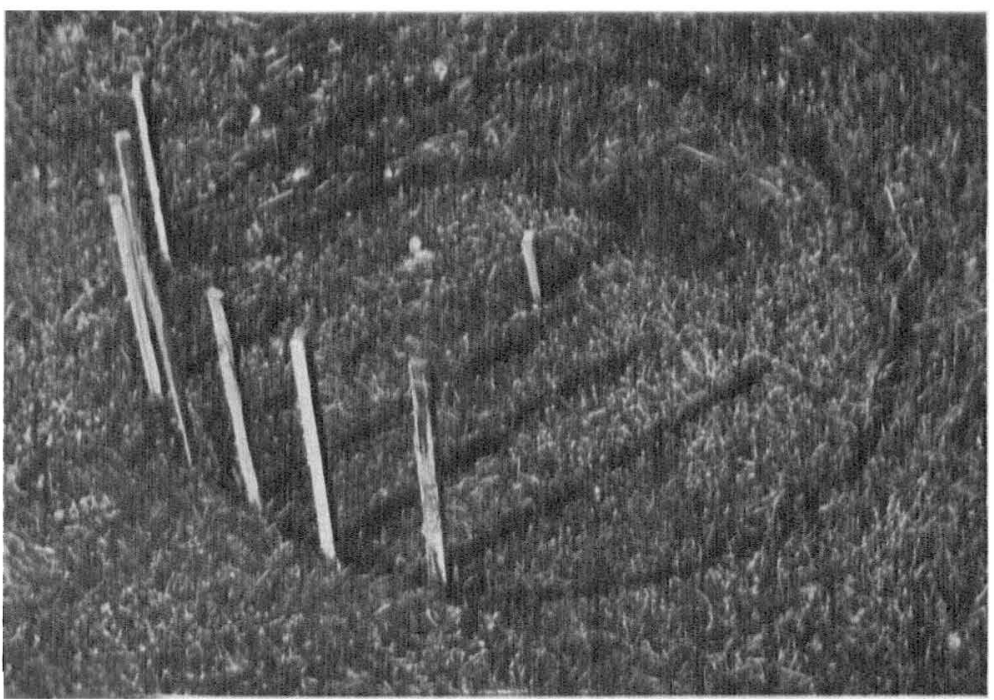

FIG. 7 .

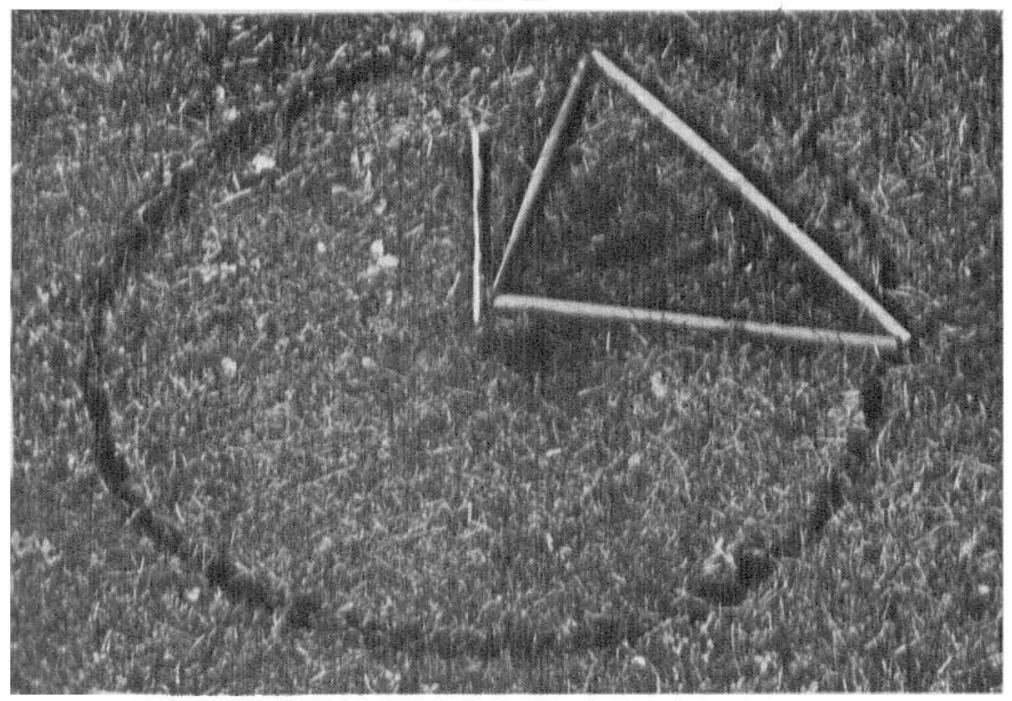

fonnarion is (a) 
lers' necessities, the favourite form being the ring dial, supplanted in the sixteenth and seventeenth centuries by the shepherd's or pillar dial. I have not found, however, in this country either of these portable sundials still in use by shepherds, but $I$ have obtained both the forms, as shown in Figs. I and 3 (Plate I.), from the Pyrenees and Tyrol respectively, where they are still in use by shepherds.*

The sundial photographed in Fig. I is used near Laz and Gavarnie in the Pyrenees, where it is sold for from forty centimes to a franc in all the little village stores. It consists of a small cylinder of boxwood marked round the base with the initials of the months, and with curves round it leading to a vertical column of hour numbers. The removable top carries a small tin gnomon, which can be turned into line with the stem and sheathed in the cylinder of the sundial. For use, the gnomon is set above the vertical line indicated by the initial of the proper month. The shepherd stands with his back to the sun, and holds the appliance up by means of a string attached to the top knob. The shadow of the gnomon then falls on the cylinder, and on following up the line next below the end of the shadow the next hour can be read off. I used such a dial myself in the Pyrenees, and found it perfectly accurate. Of course a dial of this kind must be specially designed for the particular locality in which it is to be used. A dial of somewhat similar pattern, designed for London, is shown in Fig. I (Plate X.) in the supplement to James Ferguson's Lectures on Select Subjects, etc., gth edition, 1799.

The other form of portable dial, photographed in Fig. 3 (Plate I.), was obtained in the Tyrol by Mr. H. C. Collyer. It consists of a small flat band of brass, bent into a ring of about $x \frac{1}{2}$ inches diameter, over part of which slides a second brass piece with a small perforation which passes over a narrow slit in the inner ring. The outer piece is adjusted for the time of year by means of a graduated scale, and the ray of light, passing through the perforation and slit when the dial is held

\footnotetext{
* In the discussion which followed my paper, Mr. Ilildburgh stated that portable dials were still in use in Sweden, of a type similat to that shown in Fig. 3 .
} 
up, falls upon a graduated scale on the inside of the inner ring, from which the time can be read off.

E. Lovetr.

\section{Amulets from Costers' Barrows in London, Rome, AND NAPLiSS.}

(WITI PLATR III.)

(Read at Meeling, November $19 t h, 1908$.

Ir is a common idea that few traces of folk-beliefs can be found in great cities, but my own experience is that, at any rate for the seeker after amulets, there is no better hunting ground than the hawkers' handbarrows in the poorest parts or slums of such dense aggregations of people as London, Rome, and Naples. In a visit to Italy last summer I obtained a large number of amulets used by the poorer people in Rome and Naples, and Fig. 9 (Plate III.) shows a group of purchases in these cities. The amulets were found, mixed with ex votos and modern religious medals and symbols, for sale, not to the visitor and curio-hunter who rarely invade the slums, but to the poor city dweller and to the peasant visiting the city. The first and third in the top row are metal wavy horns; the second is a tusk; the three in a vertical line on the extreme right and the one in the bottom left-hand corner are artificial horns cut from pearl shells; the largest object is an artificial horn cut from the lip of a conch shell; and the four remaining objects are two pincers of a crab of different sizes, a tooth, and the core of a goat's horn. The general resemblance of these amulets to those shown in the upper part of the Plate is quite obvious, although the group in Fig. 8 was collected from the costers' barrows in the poor man's markets of London.

For many years I have been in touch with some of the Iondon street dealers in unconsidered trifles, and $I$ am much surprised to find how much they know as to the reasons for carrying certain amulets. Phallic symbols, such as the glass and cornelian drops 